\title{
Use of Ganoderma lucidum (Ganodermataceae, Basidiomycota) as Radioprotector
}

\author{
Aránzazu González ${ }^{1,2}$, Violeta Atienza ${ }^{3}$, Alegría Montoro ${ }^{4,5}$ and Jose M. Soriano ${ }^{1,2, * \mathbb{C}}$ \\ 1 Food \& Health Lab, Institute of Materials Science, University of Valencia, 46980 Paterna, Valencia, Spain; \\ aranzazugonzalez999@gmail.com \\ 2 Joint Research Unit on Endocrinology, Nutrition and Clinical Dietetics, University of Valencia-Health \\ Research Institute La Fe, 46021 Valencia, Spain \\ 3 Department of Botany and Geology, Faculty of Biological Sciences, University of Valencia, 46100 Burjassot, \\ Valencia, Spain; M.Violeta.Atienza@uv.es \\ 4 Radiation Protection Service, University and Polytechnic Hospital La Fe, 46021 Valencia, Spain; \\ montoro_ale@gva.es \\ 5 Biomedical Imaging Research Group GIBI230, Health Research Institute La Fe, 46021 Valencia, Spain \\ * Correspondence: jose.soriano@uv.es; Tel.: +34-963-543-056
}

Received: 26 March 2020; Accepted: 15 April 2020; Published: 19 April 2020

\begin{abstract}
For millennia, naturopaths and physicians have used Ganoderma lucidum (reishi mushroom) for its diverse therapeutic properties, as recorded in the oldest Chinese herbal encyclopedia. Indeed, a radioprotective effect has been reported in the isolated components of its extracts. A systematic review and meta-analyses (PRISMA) was conducted in March 2020, searching databases including PubMed, Scopus, Embase, and Google Scholar, along with Clinical Trials. The inclusion criteria were ex vivo, in vitro, and in vivo studies, with full texts in English, conducted to determine the radioprotective benefits of G. lucidum, or reports in which ionizing radiation was used. From a total number of 1109 records identified, 15 full text articles were eligible, none of them were clinical trials. In vivo studies reveal the efficiency of G. lucidum aqueous extracts of polysaccharides and triterpenes in mice exposed to $\gamma$-rays. In plasmid, they can reduce radiation damage as an increment of the open circular form, as well as increase the DNA extension, as shown in vitro studies. Ex vivo studies conducted in human blood cells show the radioprotective effect of $\beta$-glucan of aqueous extract of G. lucidum, nevertheless, its implementation as radioprotector to humans is in need of further clinical research studies.
\end{abstract}

Keywords: Ganoderma lucidum; radioprotector; ex vivo; in vivo; in vitro; reishi mushroom; review

\section{Introduction}

Ganoderma lucidum (Curtis) P. Karst. (Ganodermataceae Polyporales) [1,2] is an annual wood-degrading Basidiomycota (Figure 1) that is frequently dimidiate, in the form of a stipulated shelf, hat or pileus of 40-200 (300) $\mathrm{mm}$ in diameter, irregularly rounded, oval, reniform or flabeliform (fan-shaped), and is frequently stipulated centrally or laterally. Table 1 shows some common names [3].

For habitat and distribution, G. lucidum is widely distributed in the world, typically in tropical and temperate regions in Europe, North America, and Asia. It lives as a saprotroph on a wide variety of trees from different families, mainly at the base of broad-leaved tree trunks, and more rarely on conifers. It is exceptionally parasitic, causing wood rot. In the natural environment it is a rare species that grows at the base of the trunks, even buried, of old trees, especially on maple [4]. G. lucidum has been recorded in the oldest Chinese herbal encyclopedia, called Shen-Nong-Ben-Cao-Jing ("The Herbal Classic of the Divine Plowman") [5], edited during the Han Dynasty in China in about 
$2700 \mathrm{BC}$, and used in Oriental traditional medicine. Nowadays, it is utilized due to its beneficial effects, including antitumor [6], anti-angiogenic [7], anti-inflammatory [8], anti-herpetic [9], anti-microbial [10], anti-hypertensive [11], hypocholesterolemic [12], anti-histamine [13], anti-complement [14], hepatoprotective [15], and radioprotective [3] among other properties [16], this last effect being detected in the extracts and in isolated polysaccharide components [17]. The use of radioprotective compounds in research are applied in a radioactive environment, such as in space exploration, for individuals handling nuclear emergencies, radiation workers, and individuals subjected to diagnostic and therapeutic radiation exposures, as the compounds can minimize the effects of single-strand breaks, double-strand breaks (DSB), base damage and DNA-protein cross-links [18]. The aim of this systematic review was to evaluate the radioprotective effect of G. lucidum.

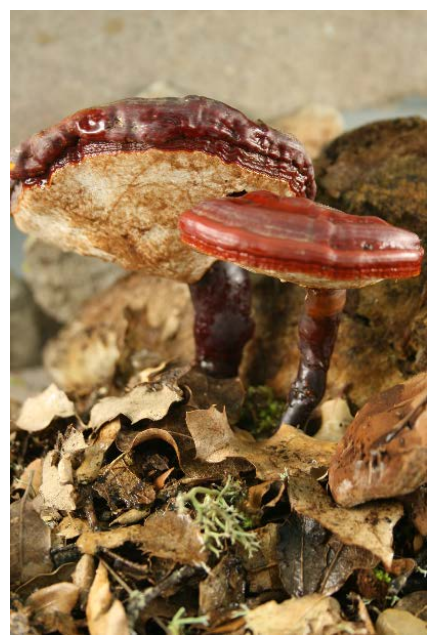

Figure 1. Ganoderma lucidum at the base of Quercus coccifera in Spain, Castellón, El Toro, 19 November, 2008, Mir and Atienza, Herbarium VAL-Myco 134.

Table 1. Common name of Ganoderma lucidum in several languages, adapted from [3].

\begin{tabular}{|c|c|c|}
\hline Language & Local Name & Other Characteristics \\
\hline Spanish & Pipa & - \\
\hline Catalan & Paella, pipa. & - \\
\hline $\begin{array}{l}\text { Chinese } \\
\text { (Pinyin) }\end{array}$ & $\begin{array}{l}\text { 靈芝 (Lingzhi) is first collected during the Eastern } \\
\text { Han Dynasty (AD 25-220). Lingzhi is composed of } \\
\text { 靈 (ling) which means “spirit", supernatural, soul, } \\
\text { miracle, sacred, divine; and 芝 (zhi) is a word that it } \\
\text { does not have an exact translation in non-eastern } \\
\text { languages and refers to a set of varied objects such } \\
\text { as plants, fungi, mushrooms, and seeds. }\end{array}$ & $\begin{array}{l}\text { In China some Ganoderma species are differentiated } \\
\text { as 赤芝 (chizhi), “Red mushroom”; or G. lucidum and } \\
\text { 紫芝 (zizhi), “Purple mushroom”. Other Chinese } \\
\text { names are 瑞芝 (ruizhi), “Propitious mushroom”; 神 } \\
\text { 芝 (shenzhi), “Divine mushroom”; 木靈芝 } \\
\text { (mulingzhi), refers to tree or wood; 仙草 (xiancao), } \\
\text { “Plant of immortality or immortal”; and 靈芝草. } \\
\text { (lingzhicao) or 芝草 (zhicao), “Mushroom plant”. }\end{array}$ \\
\hline English & Glossy ganoderma, shiny polyporus. & 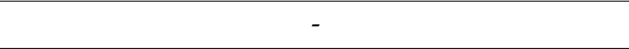 \\
\hline French & Polypore luisant, ganoderme luisant. & - \\
\hline German & Lackporling, glänzender lackporling. & - \\
\hline Japanese & Reishi ( 芝). & $\begin{array}{l}\text { Other literary terms for this mushroom are zuisō (瑞 } \\
\text { 草), “Propitious plant"; and sensō (仙草), “Plant of } \\
\text { immortality". A name used is mannentake (万年 茸), } \\
\text { “10,000-year-old mushroom". Written Japanese uses } \\
\text { shi or shiba (芝) for grass and uses take o kinoko (茸) } \\
\text { for “mushroom." }\end{array}$ \\
\hline Korean & $\begin{array}{c}\text { Yeong Ji or Yung Gee (영지, 靈芝). It is also called } \\
\text { Seon-cho (선초, 仙草), Gil-sang-beo-seot (길상 버섯, } \\
\text { 吉祥 茸), Yeong ji cho (영지 초, 靈芝 草) or Jeok hee } \\
\text { (적지, 赤芝). }\end{array}$ & $\begin{array}{l}\text { It is named according to their colors: Ja-ji (자지, 紫 } \\
\text { 芝), if it is purple; Heuk-ji (흑지, 黑 芝), black; } \\
\text { Cheong-ji (청지, 靑 芝), blue or green; Baek-ji (백지, } \\
\text { 白芝), white; Hwang-ji (황지, 黃 芝), yellow. }\end{array}$ \\
\hline Vietnamese & Linh chi & $\begin{array}{l}\text { Often used with (nấm Linh Chi), which is the } \\
\text { equivalent of G. lucidum or reishi mushroom }\end{array}$ \\
\hline
\end{tabular}




\section{Methods}

This systematic review was developed according to the Preferred Reporting Items for Systematic Reviews and Meta-Analyses (PRISMA) statement [19] (Figure 2) and conducted in March 2020 using PubMed, Scopus, Embase, and Google Scholar, along with www.clinicaltrials.gov, for completed or ongoing clinical trials.

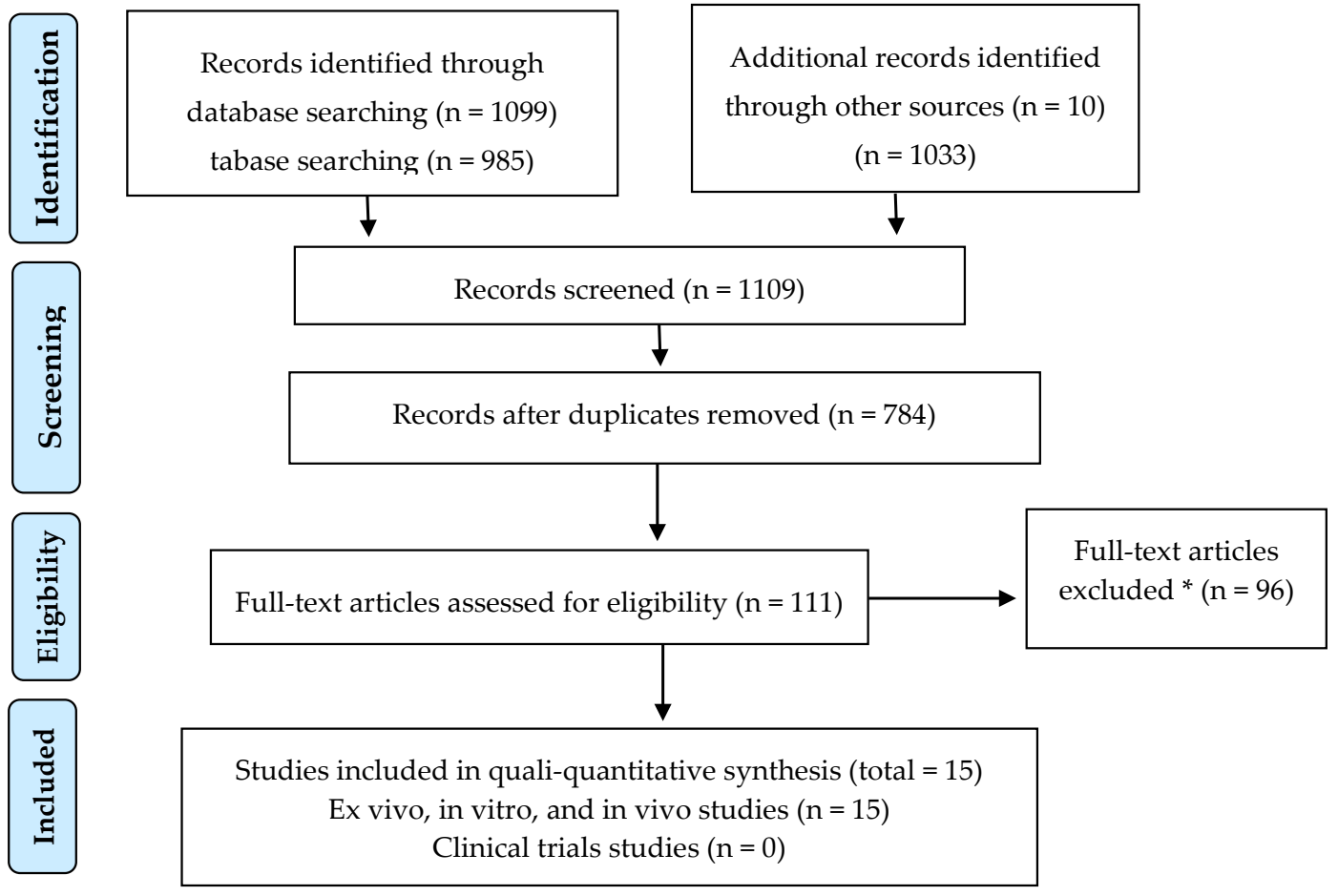

Figure 2. PRISMA (Preferred Reporting Items for Systematic Reviews and Meta-Analyses) flow diagram for studies retrieved through the searching and selection process. * The reasons for the exclusion of articles were the lack of critical information and methodological shortcomings (see Methods section).

Authors decided not to limit the year of publication. Specifically, we used the keywords "radiation", "radiation protection", "radioprotector", "Ganoderma lucidum", "Ganoderma", and common name in any language and any of their homotypic and heterotypic synonyms [3]; (Agarico-igniarium trulla Paulet., Agaricus lignosus Lam., Agaricus pseudoboletus Jacq., Boletus castaneus Weber., Boletus crustatus J.J. Planer., Boletus dimidiatus Thunb., Boletus flabelliformis Leyss., Boletus laccatus Timm., Boletus lucidus Curtis., Boletus ramulosum var. flabelliformis (Leyss.) J.F. Gmel., Boletus rugosus Jacq., Boletus supinus var. castaneus (Weber) J.F. Gmel., Boletus verniceus Brot., Boletus vernicosus Bergeret., Fomes japonicus (Fr.) Sacc., Fomes lucidus (Curtis) Sacc., Ganoderma japonicum (Fr.) Sawad., Ganoderma mongolicum Pilát., Ganoderma nitens Lázaro Ibiza., Ganoderma ostreatum Lázaro Ibiza., Ganoderma pseudoboletus (Jacq.) Murrill., Grifola lucida (Curtis) Gray., Phaeoporus lucidus (Curtis) J. Schröt., Placodes lucidus (Curtis) Quél., Polyporus japonicus Fr., Polyporus laccatus (Timm) Pers., Polyporus laccatus (Timm) Pers., Polyporus lucidus (Curtis) Fr., Polyporus lucidus var. japonicus (Fr.) Cleland \& Cheel., and Scindalma japonicum (Fr.) Kuntze.).

As inclusion criteria, we considered published ex vivo, in vitro, and in vivo studies [20], along with clinical trials with full texts that were conducted to determine the radioprotective effect of G. lucidum, and studies in English in which ionizing radiation was used. The following information was obtained: author name, year of publication, subject/cell/DNA, radiation type and dose, dose/concentration, and main outcomes. For clinical trials, if it was applicable, we used the Jadad scale [21]. On the other hand, for exclusion criteria the reasons were the following: 1. studies in which G. lucidum was not used; 2. G. lucidum used in combination with other agents; 3 . studies that made use of other forms of 
radiation such as ultraviolet (UV), fluorescence, cosmic, etc.; 4. the effect of G. lucidum evaluated with chemotherapy instead of radiation therapy; 5 . conference abstracts; 6 . simulation studies; 7 . review articles; 8. case reports; 9. letters; 10. editorials; 11. unpublished data; 12. articles without full texts; and 13. non-English articles.

Two teams of paired reviewers (A.G., V.A., A.M., and J.M.S.) with expertise in medical and health evaluations, and training in research methodology, independently screened titles, abstracts, and full texts for eligibility, assessed generalizability, and collected data from each eligible study using standardized pilot tested forms with detailed instructions. Reviewers resolved disagreement through discussion.

\section{Results}

A total number of 1109 records were identified through database searching. After the screening of duplicates and irrelevant studies, 15 full text articles that were assessed remained eligible, all of which included in ex vivo, in vitro, and in vivo studies. None of the ten clinical trials, as reflected in www.clinicaltrials.gov, assayed G. lucidum as radioprotectors (Figure 2). Tables 2-4 demonstrate, respectively, ex vivo (3), in vivo (13), and in vitro (4) studies.

Table 2. Summary of articles focused on the ex vivo radioprotective effect of G. lucidum included in the systematic review.

\begin{tabular}{|c|c|c|c|c|}
\hline Cell & $\begin{array}{l}\text { Radiation Type } \\
\text { and Dose (Gy) }\end{array}$ & Dose/Concentration & Main Outcomes & Reference \\
\hline Leukocytes & $\gamma$-ray, 50 & $\begin{array}{l}50 \mu \mathrm{g} / \mathrm{mL} \text { aqueous } \\
\text { extract of } \mathrm{G} . \text { lucidum }\end{array}$ & $\begin{array}{l}\beta \text {-glucan protected DNA against } \\
\text { radiation-induced single-strand } \\
\text { breaks; reduced the increase in \% tail } \\
\text { DNA, tail length, tail moment and } \\
\text { olive tail moment. }\end{array}$ & [22] \\
\hline $\begin{array}{l}\text { Human peripheral } \\
\text { blood lymphocytes }\end{array}$ & $\gamma$-ray, $0,1,2$, and 4 & $\begin{array}{l}50 \text { and } 100 \mu \mathrm{g} / \mathrm{mL} \\
\beta \text {-glucan of } G \text {. lucidum }\end{array}$ & $\begin{array}{l}\text { Reduction of comet parameters, such } \\
\text { as the \% tail DNA, tail length, tail } \\
\text { moment and olive tail moment. }\end{array}$ & [23] \\
\hline $\begin{array}{l}\text { Human peripheral } \\
\text { blood lymphocytes }\end{array}$ & $\gamma$-ray, 2 & $\begin{array}{l}10,50, \text { and } 100 \mu \mathrm{g} / \mathrm{mL} \\
\text { aqueous extract of } \\
\text { G. lucidum }\end{array}$ & $\begin{array}{l}\text { Reduction of the \% tail DNA, tail } \\
\text { length, tail moment and olive } \\
\text { tail moment. }\end{array}$ & [20] \\
\hline
\end{tabular}

Table 3. Summary of articles focused on the in vivo radioprotective effect of G. lucidum included in the systematic review.

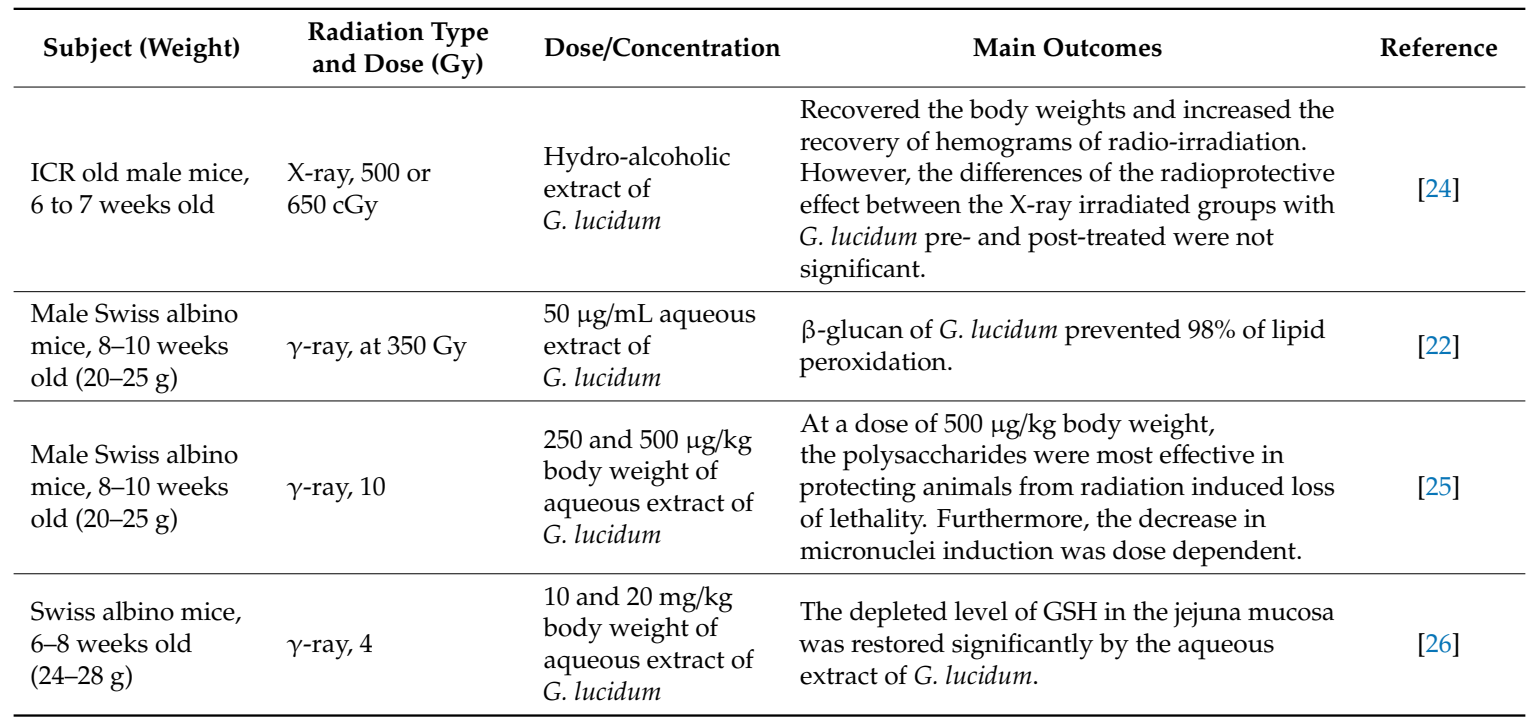


Table 3. Cont

\begin{tabular}{|c|c|c|c|c|}
\hline Subject (Weight) & $\begin{array}{l}\text { Radiation Type } \\
\text { and Dose (Gy) }\end{array}$ & Dose/Concentration & Main Outcomes & Reference \\
\hline $\begin{array}{l}\text { Swiss albino mice, } \\
6-8 \text { weeks old } \\
(26-30 \mathrm{~g})\end{array}$ & $\gamma$-ray, 4 & $\begin{array}{l}10 \text { and } 20 \mathrm{mg} / \mathrm{kg} \\
\text { body weight of } \\
\text { aqueous extract of } \\
\text { G. lucidum }\end{array}$ & $\begin{array}{l}\text { Reduction of the serum MDA levels compared } \\
\text { to the irradiated group. Tissue GSH was } \\
\text { maintained at normal levels after } \\
\text { administration of polysaccharides. }\end{array}$ & [27] \\
\hline $\begin{array}{l}\text { Swiss albino mice, } \\
6-8 \text { weeks old } \\
(28-32 \mathrm{~g})\end{array}$ & $\gamma$-ray, 4 and 8 & $\begin{array}{l}250 \text { and } 500 \mu \mathrm{g} / \mathrm{kg} \\
\text { body weight of } \\
\beta \text {-glucan of } \\
\text { G. lucidum }\end{array}$ & $\begin{array}{l}\text { Significant reduction in the number of aberrant } \\
\text { cells and different types of aberration, } \\
\text { including polyploidy and cells with } \\
\text { pulverization, were observed in both } \beta \text {-glucan } \\
\text { administration. }\end{array}$ & [28] \\
\hline $\begin{array}{l}\text { Swiss albino mice, } \\
8-10 \text { weeks old } \\
(22-25 \mathrm{~g})\end{array}$ & $\gamma$-ray, 4 & $\begin{array}{l}200 \mu \mathrm{g} / \mathrm{kg} \text { body } \\
\text { weight of aqueous } \\
\text { extract of } \\
\text { G. lucidum }\end{array}$ & $\begin{array}{l}\text { Protection to normal tissues against gamma } \\
\text { radiation-induced DNA damage, whereas in } \\
\text { sparing tumor tissues, the extract offered no } \\
\text { protection against radiation-induced cellular } \\
\text { DNA damage. }\end{array}$ & [29] \\
\hline $\begin{array}{l}\text { ICR female mice, } \\
6-8 \text { weeks old } \\
(18-22 \mathrm{~g})\end{array}$ & $\gamma$-ray, 3 and 6 & $\begin{array}{l}\text { 13.4, } 26.6, \\
\text { and } 40.0 \mathrm{mg} / \mathrm{kg} \text { of } \\
\text { aqueous extract of } \\
\text { G. lucidum }\end{array}$ & $\begin{array}{l}\text { Aqueous extract of G. lucidum did not reduce } \\
\text { the impact of radiation on WBC levels, but } 26.6 \\
\text { and } 40 \mathrm{mg} / \mathrm{kg} \text { of aqueous extract of G. lucidum } \\
\text { treatment demonstrated that MDA levels were } \\
\text { significantly decreased, the SOD activity was } \\
\text { restored to near normal levels, the micronuclei } \\
\text { frequency was reduced, and the nucleated cell } \\
\text { count in bone marrow was significantly } \\
\text { increased by aqueous extract of G. lucidum } \\
\text { treatment in a dose-dependent manner. }\end{array}$ & [31] \\
\hline $\begin{array}{l}\text { Male Swiss albino } \\
\text { mice }(23-27)\end{array}$ & $\gamma$-ray, 2.5 & $\begin{array}{l}50 \text { and } 100 \mathrm{mg} / \mathrm{kg} \\
\text { body weight of } \\
\text { total triterpenes of } \\
\text { G. lucidum }\end{array}$ & $\begin{array}{l}\text { The treatment with } 100 \mathrm{mg} / \mathrm{kg} \text { body weight of } \\
\text { total triterpenes effectively reduced the } \\
\text { percentage of MNPCE nearly to normal levels. }\end{array}$ & [20] \\
\hline $\begin{array}{l}\text { Male Swiss albino } \\
\text { mice }(23-27 \mathrm{~g})\end{array}$ & $\gamma$-ray, 2 & $\begin{array}{l}25,50, \text { and } 100 \mu \mathrm{g} \\
\text { total triterpenes of } \\
\text { G. lucidum }\end{array}$ & $\begin{array}{l}\text { Effective in preventing DNA laddering and } \\
\text { DNA damage; reduced apoptotic cells and the } \\
\text { formation of intracellular ROS. Furthermore, } \\
\text { endogenous antioxidant enzyme activity was } \\
\text { enhanced in the splenic lymphocytes } \\
\text { following irradiation. }\end{array}$ & [33] \\
\hline $\begin{array}{l}\text { BALB/c nude mice, } \\
5 \text { to } 6 \text { weeks old } \\
(18-22 \mathrm{~g})\end{array}$ & X-ray, 16 or $20 \mathrm{~Gy}$ & $\begin{array}{l}\text { GLSO@P188/PEG } 400 \\
\text { nanosystem (NS) }\end{array}$ & $\begin{array}{l}\text { This NS could reverse X-ray-induced cardio } \\
\text { dysfunction, improve long-term renovation } \\
\text { processes, and attenuate chronic cardiac } \\
\text { fibrosis and necrosis from X-rays. }\end{array}$ & [34] \\
\hline
\end{tabular}

* The diameter of the tumor reached approximately $(10 \mathrm{~mm})$; AFP: alpha-fetoprotein, FGL: fermentation filtrate of G. lucidum, GSH: reduced glutathione, IL-2: interleukin-2, MNPCE: micronucleated polychromatic erythrocytes, MDA: malondialdehyde, ROS: reactive oxygen species, and SOD: superoxide dismutase. 
Table 4. Summary of articles focused in vitro radioprotective effect of Ganoderma lucidum included in the systematic review.

\begin{tabular}{|c|c|c|c|c|}
\hline Cell/DNA & $\begin{array}{l}\text { Radiation Type } \\
\text { and Dose (Gy) }\end{array}$ & Dose/Concentration & Main Outcomes & Reference \\
\hline $\begin{array}{l}\text { Plasmid pBR322 } \\
\text { DNA }\end{array}$ & $\gamma$-ray, 25 & $\begin{array}{l}1,5,10,25 \text { and } \\
50 \mu \mathrm{g} \text { total } \\
\text { triterpenes of } \\
\text { G. lucidum }\end{array}$ & $\begin{array}{l}\text { Reduction in the open circular form in a } \\
\text { dose-dependent manner which obtained a } \\
\text { retention of } 98.87 \% \text { of the supercoiled form } \\
\text { with } 50 \mu \mathrm{g} \text { total triterpenes. }\end{array}$ & [20] \\
\hline $\begin{array}{l}\text { Plasmid pBR322 } \\
\text { DNA }\end{array}$ & $\gamma$-ray, 50 & $\begin{array}{l}50 \mu \mathrm{g} / \mathrm{mL} \text { aqueous } \\
\text { extract of } \\
\text { G. lucidum }\end{array}$ & $\begin{array}{l}\text { Protection to the plasmid DNA to an extent } \\
\text { of } 89.53 \% \text {. }\end{array}$ & [22] \\
\hline $\begin{array}{l}\text { Rat cardiomyocytes } \\
\text { (H9C2 cells) }\end{array}$ & X-ray, 2, 8, $16 \mathrm{~Gy}$ & $\begin{array}{l}\text { GLSO@P188/PEG } 400 \\
\text { nanosystem (NS) }\end{array}$ & $\begin{array}{l}\text { Any post-treated strategy after X-ray } \\
\text { irradiation (repair strategy) exhibited relatively } \\
\text { inefficient effects, compared with pre-treated } \\
\text { strategies on H9C2 cells from X-rays. The ideal } \\
\text { strategy of pre-treated GLSO@P188/PEG } 400 \text { NS } \\
\text { before irradiation for } 4-8 \text { h showed an efficient } \\
\text { protection effect on H9C2 cells from X-rays } \\
(16 \text { Gy), leading to an increase of cell viability } \\
\text { of } 101.4 \%-112.3 \%\end{array}$ & [34] \\
\hline M13mp19 RF DNA & $\begin{array}{l}\text { X-ray, } 10,20 \text { and } \\
30 \text { Gy }\end{array}$ & $\begin{array}{l}\text { Hot-water extract } \\
\text { of G. lucidum }\end{array}$ & $\begin{array}{l}\text { Protection against hydroxyl radical-induced } \\
\text { DNA strand breaks }\end{array}$ & [35] \\
\hline
\end{tabular}

The lowest number of studies was obtained using the ex vivo procedure due to technical difficulties in preparation and maintenance of isolated cells in comparison with other methods (in vivo and in vitro). Pillai et al. [22] used an aqueous extract of G. lucidum and observed a radioprotective effect, but it is important to relate that the major constituents of the aqueous extract of this mushroom are polysaccharides, as in $\beta$-glucan [23].

For in vivo studies (Table 3), two out of the 13 that were published used X-ray, being the most common $\gamma$-ray. The three most used preparations of G. lucidum are polysaccharides, aqueous extracts, and triterpenes, and all the literature from these studies show that their efficiency is in a dose-dependent manner and they are not toxic at the radioprotective dose. Gao et al. [36] indicated that the polysaccharides are among the major source of the pharmacologically active constituents in G. lucidum. In fact, the major constituent of the aqueous extract of this mushroom is polysaccharides [25]. The effectiveness of this long chains of carbohydrate molecule is observed in the reduction of malondialdehyde (MNA) [27,31], micronuclei induction $[25,31]$, and in the increase in both the reduced glutathione (GSH) pool $[26,27]$ and superoxide dismutase (SOD) activity [31]. For the triterpenes of G. lucidum, the radioprotective effect is observed with the reduction of micronucleated polychromatic erythrocytes (MCNE) [20], apoptotic cells [33], and reactive oxygen species (ROS) [33]; meanwhile, in aqueous extract, the effect exhibited is a reduction of lipid peroxidation [22].

For in vitro studies, the use of plasmid pBR322 DNA is viewed as tool with interest to assess the radioprotective effects due to radiation induced damage, as an increase in open circular form or decrease in supercoiled form of plasmid DNA. The application in plasmid of aqueous extract [22] or total triterpenes [20] of G. lucidum can reduce open circular form or increase DNA extension, respectively.

\section{Discussion}

Nowadays, the high global demand for G. lucidum is associated with its various pharmacological and therapeutic properties [37,38], focusing on its chemical compounds [39]. Briefly, the bioactive substances in the mushroom can be found in several of its parts, such as the mycelium and fruit body [4]. The most important types of these compounds are alkaloids, enzymes, glycoproteins, minerals, nucleotides, polysaccharides, proteins, steroids, triterpenes, and unsaturated fatty acids [39-44]. However, literature has reflected that the classification of the hydrophilic and hydrophobic properties of these compounds is useful to understand their effect as radioprotective compounds. Polysaccharides are hydrophilic [40], hence abundant in decoctions, whereas triterpenes are not [33]. In fact, Dai et al. [34] suggested that G. lucidum spore oil, which although it can be useful as a radioprotector, has the drawback 
of poor water solubility, which remains a major obstacle for their further development and clinical application in human health care. For this reason, these authors developed a GLSO@P188/PEG400 nanosystem (NS) to improve the efficiency of the radioprotective treatment, especially when this system has functional food composites with hydrophobic defects, such as triterpenes, but not polysaccharides.

On the other hand, a major drawback of studies using mushroom extract is that its chemical composition is not characterized. Extracts can have different chemical compounds and have different concentrations even between batches. This is important, as knowing that synergies or antagonisms can exist between each of the compounds, could have repercussions on the efficacy of the extract when studying it. According to the Montoro et al. [45], the characterization of the extracts should be an essential factor in all the studies of extracts.

\section{Conclusions}

Ex vivo studies conducted in human blood cells (leukocytes, and human peripheral blood lymphocytes) show the radioprotective effect of $\beta$-glucan of aqueous extract of G. lucidum against $\gamma$-ray radiation-induced damage. In plasmid, they can reduce radiation damage as an increment of the open circular form, as well as increase the DNA extension, as shown in vitro studies. In vivo studies reveal the efficiency of G. lucidum aqueous extracts of polysaccharides and triterpenes in mice exposed to $\gamma$-rays. Yet we must not forget that the doses of these compounds or the radiation used in the reviewed studies cannot be directly correlated to humans; therefore, further studies are required for its clinical implementation as a radioprotector.

Author Contributions: A.G., V.A., A.M., and J.M.S. were responsible for the design and the review. A.G., V.A., and J.M.S. wrote the manuscript. J.M.S. had primary responsibility for the final content. All authors have read and agreed to the published version of the manuscript.

Funding: This research was funded by The Spanish Nuclear Safety Council (2696/SRO).

Conflicts of Interest: The authors declare no conflict of interest.

\section{References}

1. Roumeguère, C. Champignon rapportés en 1880 d'une excursion botanique en Egypte et en Palestine par M. William Barbay. Revue Mycologique Toulouse 1881, 3, 23-25.

2. Hapuarachchi, K.K.; Wen, T.C.; Deng, C.Y.; Kang, J.C.; Hyde, K.D. Mycosphere essays 1: Taxonomic confusion in the Ganoderma lucidum species complex. Mycosphere 2015, 6, 542-559. [CrossRef]

3. Atienza, V.; Montoro, A.; Sebastiá, N.; Soriano, J.M. Natural organisms with effect radioprotective. In The Latest Advances in Radioprotectors of Natural Origin; Soriano, J.M., Montoro, A., Eds.; The Spanish Nuclear Safety Council: Madrid, Spain, 2013; pp. 115-205.

4. Wachtel-Galor, S.; Yuen, J.; Buswell, J.A.; Benzie, I.F. Ganoderma lucidum (Lingzhi or Reishi). In Herbal Medicine: Biomolecular and Clinical Aspects, 2nd ed.; Benzie, I.F.F., Wachtel-Galor, S., Eds.; CRC Press/Taylor \& Francis: Boca Ratón, FL, USA, 2011; pp. 175-200.

5. Gu, G.G. Reprint of Shen Nong Ben Cao Jing (1844); Lanzhou University Press: Lanzhou, China, 2009.

6. Yuen, J.W.; Gohel, M.D.I. Anticancer effects of Ganoderma lucidum: A review of scientific evidence. Nutr. Cancer 2005, 53, 11-17. [CrossRef] [PubMed]

7. Jana, P.; Acharya, K. Mushroom: A new resource for anti-angiogenic therapeutics. Food Rev. Int. 2020, in press. [CrossRef]

8. Barbieri, A.; Quagliariello, V.; Del Vecchio, V.; Falco, M.; Luciano, A.; Amruthraj, N.J.; Nasti, G.; Ottaiano, A.; Berretta, M.; Laffaioli, R.V.; et al. Anticancer and anti-inflammatory properties of Ganoderma lucidum extract effects on melanoma and triple-negative breast cancer treatment. Nutrients 2017, 9, 210. [CrossRef] [PubMed]

9. Eo, S.K.; Kim, Y.S.; Lee, C.K.; Han, S.S. Antiherpetic activities of various protein bound polysaccharides isolated from Ganoderma lucidum. J. Ethnopharmacol. 1999, 68, 175-181. [CrossRef]

10. Cör, D.; Knez, Ž.; Knez Hrnčič, M. Antitumour, antimicrobial, antioxidant and antiacetylcholinesterase effect of Ganoderma lucidum terpenoids and polysaccharides: A review. Molecules 2018, 23, 649. [CrossRef] 
11. Shevelev, O.B.; Seryapina, A.A.; Zavjalov, E.L.; Gerlinskaya, L.A.; Goryachkovskaya, T.N.; Slynko, N.M.; Kuibida, L.V.; Peltek, S.E.; Markel, A.L.; Moshkin, M.P. Hypotensive and neurometabolic effects of intragastric Reishi (Ganoderma lucidum) administration in hypertensive ISIAH rat strain. Phytomedicine 2018, 41, 1-6. [CrossRef]

12. Rahman, M.A.; Hossain, S.; Abdullah, N.; Aminudin, N. Lingzhi or Reishi medicinal mushroom, Ganoderma lucidum (Agaricomycetes) ameliorates spatial learning and memory deficits in rats with hypercholesterolemia and Alzheimer's disease. Int. J. Med. Mushrooms 2020, 22, 93-103. [CrossRef]

13. Garuba, T.; Olahan, G.S.; Lateef, A.A.; Alaya, R.O.; Awolowo, M.; Sulyman, A. Proximate composition and chemical profiles of Reishi mushroom (Ganoderma lucidum (Curt: Fr.) Karst). J. Sci. Res. 2020, 12, 103-110. [CrossRef]

14. Min, B.S.; Gao, J.J.; Hattori, M. Anticomplement activity of terpenoids from the spores of Ganoderma lucidium. Planta Med. 2001, 67, 811-814. [CrossRef] [PubMed]

15. Zhao, C.; Fan, J.; Liu, Y.; Guo, W.; Cao, H.; Xiao, J.; Wang, Y.; Liu, B. Hepatoprotective activity of Ganoderma lucidum triterpenoids in alcohol-induced liver injury in mice, an iTRAQ-based proteomic analysis. Food Chem. 2019, 271, 148-156. [CrossRef] [PubMed]

16. Ahmad, M.F. Ganoderma lucidum: Persuasive biologically active constituents and their health endorsement. Biomed. Pharmacother. 2018, 107, 507-519. [CrossRef] [PubMed]

17. Chen, L.; Abulizi, A.; Li, M. Protective effect of Ganoderma (Lingzhi) on radiation and chemotherapy. In Ganoderma and Health: Pharmacology and Clinical Application; Lin, Z., Yang, B., Eds.; Springer: Singapore, 2019; pp. 119-142.

18. Smith, T.A.; Kirkpatrick, D.R.; Smith, S.; Smith, T.K.; Pearson, T.; Kailasam, A.; Hermann, K.Z.; Schubert, J.; Agrawal, D.K. Radioprotective agents to prevent cellular damage due to ionizing radiation. J. Transl. Med. 2017, 15, 232. [CrossRef] [PubMed]

19. Moher, D.; Liberati, A.; Tetzlaff, J.; Altman, D.G.; Group, P. Preferred reporting items for systematic reviews and meta-analyses: The PRISMA statement. PLoS Med. 2009, 6, e1000097. [CrossRef] [PubMed]

20. Smina, T.P.; Maurya, D.K.; Devasagayam, T.P.A.; Janardhanan, K.K. Protection of radiation induced DNA and membrane damages by total triterpenes isolated from Ganoderma lucidum (Fr.) P. Karst. Chem-Biol. Interact. 2015, 233, 1-7. [CrossRef] [PubMed]

21. Jadad, A.R.; Moore, R.A.; Carroll, D.; Jenkinson, C.; Reynolds, D.J.; Gavahan, D.J.; McQuay, H.J. Assessing the quality of reports of randomized clinical trials: Is blinding necessary? Control. Clin. Trials. 1996, 17, 1-12. [CrossRef]

22. Pillai, T.G.; Salvi, V.P.; Maurya, D.K.; Nair, C.K.K.; Janardhanan, K.K. Prevention of radiation-induced damages by aqueous extract of Ganoderma lucidum occurring in southern parts of India. Curr. Sci. 2006, 91, 341-344.

23. Pillai, T.G.; Maurya, D.K.; Salvi, V.P.; Janardhanan, K.K.; Nair, C.K. Fungal beta glucan protects radiation induced DNA damage in human lymphocytes. Ann. Transl. Med. 2014, 2, 13.

24. Hsu, H.Y.; Lian, S.L.; Lin, C.C. Radioprotective effect of Ganoderma lucidum (Leyss, ex. Fr.) Karst after X-ray irradiation in mice. Am. J. Chin. Med. 1990, 18, 61-69. [CrossRef]

25. Pillai, T.G.; Nair, C.K.K.; Janardhanan, K.K. Polysaccharides isolated from Ganoderma lucidum occurring in Southern parts of India, protects radiation induced damages both in vitro and in vivo. Environ. Toxicol. Pharmacol. 2008, 26, 80-85. [CrossRef] [PubMed]

26. Pillai, T.G. Mushroom polysaccharide protects radiation induced intestinal damage in mice. Int. J. Pharm. Biol. Sci. 2013, 3, 1-7.

27. Pillai, T.G.; Janardhanan, K.K. In vivo radio protective properties of fungal polysaccharides. Int. J. Pharm. Biol. Sci. 2013, 3, 557-562.

28. Pillai, T.G.; Devi, P.U. Mushroom beta glucan: Potential candidate for post irradiation protection. Mutat. Res. Genet. Toxicol. Environ. Mutagen. 2013, 751, 109-115. [CrossRef] [PubMed]

29. Gopakumar, G.; Martin, F.; Antony, S.K.; Pillai, T.G.; Nair, C.K.K. Preclinical studies on the use of medicinal mushroom Ganoderma lucidum as an adjuvant in radiotherapy of cancer. Curr. Sci. 2010, 99, 1084-1090.

30. Martin, F.; Nair, C.K.K. Medicinal fungus Ganoderma lucidum protects cellular DNA in mice exposed to whole-body gamma radiation. Int. J. Low Radiat. 2011, 8, 241-253. [CrossRef] 
31. Zhao, W.; Jiang, X.; Deng, W.; Lai, Y.; Wu, M.; Zhang, Z. Antioxidant activities of Ganoderma lucidum polysaccharides and their role on DNA damage in mice induced by cobalt-60 gamma-irradiation. Food Chem. Toxicol. 2012, 50, 303-309. [CrossRef]

32. Ibrahim, S.I.; El-Kabany, H. Effect of Ganoderma lucidum on the liver of mice bearing Ehrlich Solid Tumor (EST) and exposed to $\gamma$-radiation. J. Radiat. Res. Appl. Sci. 2013, 6, 175-196.

33. Smina, T.P.; De, S.; Devasagayam, T.P.A.; Adhikari, S.; Janardhanan, K.K. Ganoderma lucidum total triterpenes prevent radiation-induced DNA damage and apoptosis in splenic lymphocytes in vitro. Mutat. Res. Genet. Toxicol. Environ. Mutagen. 2011, 726, 188-194. [CrossRef]

34. Dai, C.; He, L.; Ma, B.; Chen, T. Facile nanolization strategy for therapeutic Ganoderma lucidum spore oil to achieve enhanced protection against radiation-induced heart disease. Small 2019, 15, 1902642. [CrossRef]

35. Kim, K.C.; Kim, I.G. Ganoderma lucidum extract protects DNA from strand breakage caused by hydroxyl radical and UV irradiation. Int. J. Mol. Med. 1999, 4, 273-280. [CrossRef] [PubMed]

36. Gao, J.J.; Nakamura, N.; Min, B.S.; Hirakawa, A.; Zuo, F.; Hattori, M. Quantitative determination of bitter principles in specimens of Ganoderma lucidum using high-performance liquid chromatography and its application to the evaluation of Ganoderma products (Tokyo). Chem. Pharm. Bull. 2004, 52, 688-695. [CrossRef] [PubMed]

37. Sudheer, S.; Alzorqi, I.; Manickam, S.; Ali, A. Bioactive compounds of the wonder medicinal mushroom Ganoderma lucidum. In Bioactive Molecules in Food; Mérillon, J.M., Ramawat, K.G., Eds.; Springer: Cham, Switzerland, 2019; pp. 1863-1893.

38. Paterson, R.R.M. Ganoderma a therapeutic fungal biofactory. Phytochemistry 2006, 67, 1985-2001. [CrossRef] [PubMed]

39. Boh, B.; Berovic, M.; Zhang, J. Ganoderma lucidum and its pharmaceutically active compounds. Biotechnol. Annu. Rev. 2007, 13, 265-301.

40. Li, L.F.; Liu, H.B.; Zhang, Q.W.; Li, Z.P.; Wong, T.L.; Fung, H.Y.; Zhang, J.X.; Bai, S.P.; Lu, A.P.; Han, Q.B. Comprehensive comparison of polysaccharides from Ganoderma lucidum and G. sinense: Chemical, antitumor, immunomodulating and gut-microbiota modulatory properties. Sci. Rep. 2018, 8, 1-12. [CrossRef]

41. Ulbricht, C.; Abrams, T.R.; Bent, S.; Boon, H.; Costa, D.; Dacey, C.; Guilford, J.; Giese, N.; Grimes Serrano, J.M.; Hackman, A.D.; et al. Reishi mushroom (Ganoderma lucidum): Systematic review by the natural standard research collaboration. J. Soc. Integr. Oncol. 2010, 8, 148-159.

42. Hung, W.T.; Wang, S.H.; Chen, C.H.; Yang, W.B. Structure determination of beta-glucans from Ganoderma lucidum with matrix assisted laser desorption/ionization (maldi) mass spectrometry. Molecules 2008, 13, 1538-1550. [CrossRef]

43. Sharma, C.; Bhardwaj, N.; Sharma, A.; Tuli, H.S.; Katyal, P.; Beniwal, V.; Gupta, G.K.; Sharma, A.K. Bioactive metabolites of Ganoderma lucidum: Factors, mechanism and broad spectrum therapeutic potential. J. Herb. Med. 2019, 17-18, 100268. [CrossRef]

44. Martínez-Montemayor, M.M.; Ling, T.; Suárez-Arroyo, I.J.; Ortiz-Soto, G.; Santiago-Negrón, C.L.; Lacourt-Ventura, M.Y.; Valentín-Acevedo, A.; Lang, W.H.; Rivas, F. Identification of biologically active Ganoderma lucidum compounds and synthesis of improved derivatives that confer anticancer activities in vitro. Front. Pharmacol. 2019, 10, 115.

45. Montoro, A.; Barquinero, J.F.; Almonacid, M.; Sebastià, N.; Verdu, G.; Sahuquillo, V.; Serrano, J.; Saiz, M.; Villaescusa, J.I.; Soriano, J.M. Concentration-dependent protection by ethanol extract of propolis against $\gamma$-ray-induced chromosome damage in human blood lymphocytes. Evid. Based Complement. Alternat. Med. 2011, 2011, 174853. [CrossRef]

(C) 2020 by the authors. Licensee MDPI, Basel, Switzerland. This article is an open access article distributed under the terms and conditions of the Creative Commons Attribution (CC BY) license (http://creativecommons.org/licenses/by/4.0/). 